\title{
List of Women Interviewed
}

Everyone I formally interviewed is cited parenthetically in the text following a woman's remarks. Below is an alphabetical list of names for crossreference. Although they were not formally interviewed, I have also included Sielma, Fatima, Danda, Djandira, and Marta in this list, because they are referred to frequently enough that their inclusion may prove helpful.

In order to protect women's anonymity, names are pseudonyms and biographical information is limited. For women interviewed in the ilha, I provide information regarding which tactic, liberdade or security, they chose. (These tactics are described in Chapter 5.) For women with cancer, I provide information regarding their disease. Cervical cancer ranges in severity from in situ disease, which has not invaded the stroma at all and is therefore easily removable, through stages I, II, III, and IV. Each stage corresponds to a greater extent of spread and poorer prognosis.

\section{The 'Ilha'}

Aida. She was nineteen and lived in her sister's house. She had four children and did not work. Liberdade.

Ana. Twenty years old, she lived with her family and had a partner who was married to someone else. No children. Security.

Ana Maria. She was fifty-five years old and a widow with three children. She lived in her daughter's home. Liberdade.

Ana Rodriga. Thirty-five years old, she lived with her partner and maintained the bathroom at the local elementary school. She had one child, who lived with Ana Rodriga's mother. Neither security nor liberdade.

Angelini. She was sixteen, had a newborn, and did not work. She lived in a room that her married partner rented for her. Security.

Bida. She was sixty-five, lived in her own home, had ten children, and worked as a domestic. She had a partner but he no longer lived with her, and she did not want him to. Liberdade. 
Carla. She was thirty-nine, did not work, and lived with her partner and two children in a home she owned jointly with her husband. Security.

Cesa. Forty-six years old. She was an evangelical Christian who lived with her husband and three of her children. Security.

Dalva. She was fifty-eight and a widow with four grown children. Her husband left her when she was forty-two, and she never had another partner. Her husband had since died and she both received his pension and worked as a domestic. Liberdade.

Danda. She was twenty-nine, had no children, and lived with her mother and sisters.

Dinda. Forty-two years old, she had ten children and a mentally ill husband. She did not work outside the home. Neither security nor liberdade.

Djandira. Twenty-nine years old, she had two children. She lived with various partners until building her own house after leaving her last partner, George.

Fatima. She was thirty-one, had two children, and lived in her in-law's home.

Helena. She was forty-four and worked as a domestic. She lived with her husband and six children in her own home. Security.

Josineide. Twenty-five, she lived with her husband and two children in her husband's home, and she did not work. Security.

Julia. Sixty-one years old, she was a widow who owned her own home and did not work. She had four grown children. Liberdade.

Lindalva. She was fifty, single, and did not work. She lived in her own home with one of her two children, who supported her. Liberdade.

Mama. She was fifty-three, worked as a domestic, and lived in her own home with three of her four children and two of her grandchildren. Liberdade.

Maria Jose. Twenty-eight, she lived in her father's house with her three children. She often (though not always) described herself as married but did not depend on her partner economically and was not always faithful to him. Liberdade.

Marta. She was thirty, had one child, and lived in her own home, sometimes with Ton, Rosana's husband, and sometimes just with her daughter.

Neide. She was twenty-nine and did not work. She lived in her mother's home with her three children. Her mother supported her. Liberdade.

Nen. Thirty years old, she lived with her husband and three children in her husband's house. Security.

Nene. She was thirty-five and worked as a domestic. She owned her own home and had three children. Liberdade.

Nevinha. She was forty-five, performed manicures for a living, and lived alone. She had a grown son and was single. Liberdade. 
Nida. Forty years old, she lived with her husband and three children in her husband's house. Security.

Nilza. She was thirty-six and lived with her four children and her partner in a home they owned together. Security.

Nulza. Thirty-five years old and single, she lived with her six children and supported the family by working as a cook in a local restaurant. Liberdade.

Renata. She was forty-seven and a widow. She and her three daughters lived with her mother-in-law. Liberdade.

Rosalia. She was twenty-seven, did not work, and had a partner who was married to someone else but who supported her and her two children. She lived in her brother's home. Security.

Rosana. She was twenty-five and lived in a home that her partner, who left her for Marta, still rented for her. She had four children. Security.

Sielma. She was thirty-three, had five children, and lived in a home she owned with her husband.

Simonne. Twenty-three, she lived in her grandmother's house with her two children and her partner. She did not work and was supported by her partner. Security.

Socorro. Seventy years old, she was a widow and owned her own home. No children. Liberdade.

Teresa. Forty-two years old, she worked as a domestic and lived with her mother and two children in her mother's home. Liberdade.

Tonieta. She was thirty-one, had one child, did not work, and lived with her partner. Security.

\section{Women with Cancer}

Adalgisa. Sixty-six, she was retired and had three children. She had never been married and had stage Ib cervical cancer.

Antonia. She was forty-five years old, married, and worked until she became too sick. She had five children and stage IIb cervical cancer.

Antonia Josepha. She was seventy-four, a widow, and received a pension. She had stage IIb cervical cancer.

Biu. Seventy-three, Biu had stage IIIb cervical cancer. She was a widow with thirteen children. She did not work.

Cesa. She was forty-six and worked as a domestic until she got too sick. She had two children, but did not raise either one. She never married. Since becoming sick, she lived with a former employer who took care of her. She had invasive cancer, stage unknown.

Creuza. Sixty-one years old, she worked as a domestic and lived with her husband. She had ten children and stage IIa cervical cancer. 
Dalva. She was thirty-one and had stage $\mathrm{Ib}$ cervical cancer. She did not work, had three children, and lived with her partner.

Dinaura. She was fifty years old and worked as a domestic. She was a widow with four children. She had stage IIIb cervical cancer.

Enilda. Fifty-four, she worked as a domestic and had four children. She had never been married. She had stage IIIb cervical cancer.

Ilda. She was fifty-one and had two rooms behind her house that she rented out. Her husband had abandoned her and her seven children. She had carcinoma in situ.

Ivanilda. Thirty-six years old, she worked in a factory just outside of Recife. She had five children and was helped economically by a partner who was married to someone else. She had in situ cancer.

Ivonete. Forty-eight, she had stage IIIb cervical cancer, was a widow, and was supported economically by her three children.

Josepha. She was forty-nine and worked as a domestic. She lived with her partner and six children in her own home. She had stage IIb cervical cancer.

Lucia. Thirty-four years old, she was married, had one child, worked as a domestic, and had stage Ia cervical cancer.

Luiza. Forty-five, Luiza lived with her husband and son. She did not work and had stage IIa cervical cancer.

Maria. Sixty-nine, she was a widow, had five children, and had stage IIb cervical cancer.

Maria de Lurdes. Seventy-six, Maria de Lurdes was married. She and her husband lived with their son. Maria never worked. She had invasive cancer of uncertain stage.

Maria dos Prazeres. Fifty-one, she worked as a nurse's aid. She was married, had nine children, and had stage IIb cervical cancer.

Marizete. She was forty-eight, married, and had one child. She had stage II cervical cancer. She did not work.

Marli. She was thirty-six years old, single, and supported herself in any way she could, including through prostitution and drug sales. She had stage IIIb cancer and four children, all raised by her mother.

Lurdes. Forty-four, she had in situ cancer. She had two children, lived with her husband, and had never worked.

Maria de Socorro. She was forty-nine, washed clothes for money when she felt well enough, and was married with four children. She had invasive cancer, stage unknown.

Maria Jose. She was forty-three, had stage IIIB cervical cancer, and was a widow. She and her two children moved in with her sister when she got sick.

Moça. Seventy years old, Dona Moça had been left by her husband fifteen years previously and had not had a relationship since. She had nine children, did not work, and had invasive cancer of unknown stage. 
Nen. She was forty-eight, worked in a factory outside of Recife, and had five children. Her husband sold lottery tickets. She had in situ cancer.

Nilza. She was forty-nine, sewed and sold clothes for extra money, and lived with her husband, who paid most of the bills. She had four children and invasive cancer of unknown stage.

Rute. She was thirty-two and worked as a domestic. She lived with her husband and three children. She had in situ cancer.

Severina. She was forty-three and had stage III cancer. She had three children, did not work, and lived with her husband.

Teresa. Fifty-five, she had two children and worked as a domestic. Her husband had left her several years earlier. She had stage Ib cervical cancer.

Valdeci. She was forty-four and was married with one child. She stayed at home while her husband worked. She had in situ cancer. 
